\title{
Population dynamics in ethnically diverse towns: the long- term implications of immigration
}

Link to publication record in Manchester Research Explorer

\section{Citation for published version (APA):}

Simpson, L., Gavalas, V., \& Finney, N. (2006). Population dynamics in ethnically diverse towns: the long-term implications of immigration. (CCSR Working Paper).

\section{Citing this paper}

Please note that where the full-text provided on Manchester Research Explorer is the Author Accepted Manuscript or Proof version this may differ from the final Published version. If citing, it is advised that you check and use the publisher's definitive version.

\section{General rights}

Copyright and moral rights for the publications made accessible in the Research Explorer are retained by the authors and/or other copyright owners and it is a condition of accessing publications that users recognise and abide by the legal requirements associated with these rights.

\section{Takedown policy}

If you believe that this document breaches copyright please refer to the University of Manchester's Takedown Procedures [http://man.ac.uk/04Y6Bo] or contact uml.scholarlycommunications@manchester.ac.uk providing relevant details, so we can investigate your claim.

\section{OPEN ACCESS}




\section{MANCHESTER}

\section{4}

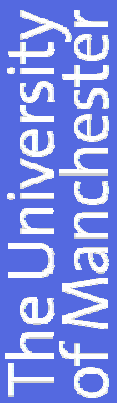

\section{Cathie Marsh Centre for Census and Survey Research}

Population dynamics in ethnically diverse towns: the long-term implications of immigration

CCSR Working Paper 2006-04

Ludi Simpson, Vasilis Gavalas and Nissa Finney

ludi.simpson@manchester.ac.uk 


\title{
Population dynamics in ethnically diverse towns: the long-term implications of immigration
}

\author{
Ludi Simpson*, Vasilis Gavalas $^{+}$and Nissa Finney ${ }^{\#}$ \\ *Centre for Census and Survey Research, University of Manchester, M13 9PL, \\ England. email: ludi.simpson@mancheser.ac.uk \\ ${ }^{+}$University of the Aegean, Department of Geography, 81100 Mytilene, Greece. \\ email: bgav@geo.aegean.gr \\ \# Department of Geography, Roxby Building, University of Liverpool, L69 7ZT, \\ England. email: nissa.finney@liv.ac.uk
}

March 2006

Ethnically diverse urban areas are often strongly influenced by the medium and longterm demographic consequences of immigration. Hypotheses regarding the population, housing and social changes following immigration are here set out in a dynamic paradigm. These are tested using a time series of census data for Oldham and Rochdale. The results show how natural growth generates dispersal of immigrant populations to new clusters. They chart the changing nature of cities, and challenge the interpretation of clustering as a negative phenomenon, instead focusing on indicators of demographic change, demand for housing and services, and social equality.

\section{Introduction}

Commentators in race-conscious societies often focus attention on ethnic composition. The association of immigrant concentration with poverty has frequently led to fears of separate development and violent confrontations, which make integration more difficult. However, a historical and demographic viewpoint shows that residential integration and separation are not as opposed as they linguistically appear to be. This paper sets out such a historical and demographic approach, measures the separation that is represented by growth of immigrant-origin populations in inner urban settlement areas, and its simultaneous movement to other areas. The extent of social stratification over time and across generations is a key secondary feature of the paper.

Sociological and statistical studies of residential racial segregation evolved from the Chicago School throughout the twentieth century, which measured the evolution of African-American ghettoes in the northern United States, contrasting their separation from White residential areas with the gradual dispersal of immigrants of European origin (Duncan and Duncan, 1955; Lieberson 1963; Taeuber and Taeuber 1965). In Western Europe, immigration during and after the second world war gave rise to population groups defined racially which by the end of the twentieth century were of sufficient size for ethnic composition to become a common academic and policy concern. In the measurement of residential composition in both the USA and European contexts "segregation has an outspoken negative connotation and is predominantly focused upon the ethnic dimension. ... The fear [of ghettoisation] is based on the idea that a sequence of events may happen which is regarded as unwanted. That sequence is: increasing spatial segregation will lead to increasing 
separation of different social and ethnic classes and population categories; in its turn, that will produce ghetto-like developments and will finally result in the disintegration of urban society." (Fortuijn et al. 1998, 367).

In Britain, racial demography has periodically been highlighted as problematic by media and commentators, most recently in 2005 following bombings in London (Phillips 2005). The ensuing debate (Dorling 2005; GLA 2005) suggests the importance not only of what is studied but also the paradigm within which the evidence is viewed. It is argued here that an emphasis on patterns of ethnic composition is not has helpful as an examination of the process by which cities develop their ethnic composition. The approach outlined in this paper provides both a prognosis and empirical results helpful to policy development.

Table I illustrates the limitation of focusing only on ethnic composition. Part (a) of the table clarifies that the number of areas in England with concentrations of nonWhite population has been growing, and that the proportion of all non-White residents who live in that area has also been growing. The conclusion that there is retreat into enclaves or ghettoes is contradicted by part (b) of the table which shows migration away from the concentrations of non-White residents, more so than of White residents. The role of this paper is to investigate the deeper processes at work that give rise to changing ethnic composition.

\section{[Table I about here]}

In past studies, different aspects of segregation have been distinguished, including concentration, isolation or exposure, centralisation, evenness and clustering, leading to the term 'hypersegregation' to denote those situations where segregation is evident by all of its aspects (Massey and Denton 1989; Wilkes and Iceland 2004). In Europe, ghettoes are rarely encountered (Peach 1996b), but increased concentrations of populations rooted in recent immigration are identified and viewed with concern (Johnston et al. 2002). In Britain the concern with concentrations of Muslim populations has been politically evident since riots in northern British cities in 2001, and the rise of the United States government 'war on terror' supported by the British government (Cantle 2001; Phillips 2005).

USA and European studies of residential segregation have in common a focus on ethnic or racial groups which are relatively poor minorities, about whom negative assumptions are so frequently made in political commentary that they also colour scientific approaches (Zuberi 2001; Simpson 2004). In particular the local proportion of minority populations is taken as the target of analysis, such that low proportions are seen as positive and high proportions a result partly of failing policy and partly of failing commitment to integration on the part of minority individuals and leaders themselves. The main scientific weakness in the current measurement of segregation is its focus on indices based on the local proportion of minorities, without measurement of the dynamic and historical causes of residential clustering.

If studies of segregation tend to ignore causes and population dynamics, studies of immigration are more frequently historical. A brief review of the older migrations of Jews, Huguenots and Irish is relevant here. Although less well quantified than modern migrations in the time of computerised census output, studies of these three groups emphasis the positive impact of residential clustering in the process of immigrant integration. Writers have emphasised that the residential concentration of Jews was a result of congregative rather than segregative forces - a result of positive identification rather than defensive separation (Kantrowitz 1982; Waterman and 
Kosmin 1987). Subsequent upward socio-economic mobility has resulted in regroupings of the Jewish population, re-identifications that have affected residential patterns, for example in London and Manchester (Newman 1985; Valins 2003).

The Huguenot immigrants, arguably 'the first modern refugees' (Hintermaier 2001), were French speaking Protestants (Calvinists) who fled to neighbouring Protestant states between the 16th and 18th centuries. Between the 1670s and the early 1700 s it is estimated that 40-50,000 Huguenot refugees came to England. (Gwynn 2002). Their settlement provides an example of clustering for economic, social, linguistic and religious reasons. As Gwynn (1985, 2-3) notes: "unused to the political and social customs as well as the language of the host society they tend to cluster together, forming a distinct minority element, perhaps for several generations, before slowly being assimilated...the communities lasted for longer than it took the refugees to acquire a reasonable knowledge of spoken and written English, communities within which they frequently intermarried and - as far as they were allowed - created their own church and work environment." Indeed, although xenophobia was common, the Huguenot refugees in England were generally welcomed because of their religion (Vigne and Littleton 2001).

Irish immigration to Britain has been an important phenomenon for the past three centuries. The mid-19th century saw particularly significant numbers of Irish immigrants in relation to the British population as a result of famines in Ireland. The Irish then constituted a third of the populations of London, Liverpool, Manchester, Birmingham and Glasgow (MacRaild 1999). By 1871 the proportion of Irish found in the main urban centres had fallen and dispersal continued. However, the importance of cultural and religious networks remained and some have argued that detailed studies of settlement patterns still reveal distinct Irish clusters (e.g. Busteed, Hodgson and Kennedy 1992; Busteed 2000; Neal 2000). Positive and negative reasons for clusters in the 19th century have been cited, assertive Irishness as well as "defensive reactions against the alien and occasionally actively hostile environment they encountered" (Busteed 2000, 122). Despite these observed concentrations considerable effort has been expended by historians of the Irish in Britain to demonstrate that the Irish were not socially segregated (Busteed 2000).

By way of summary, for each of the Jewish, Huguenot and Irish groups ethnic and religious identity was important as they established their new lives and religious institutions were a crucial foci for this sense of belonging. Chain migration to the initial settlement areas consolidated their geographical significance. These three immigrant groups also shared experiences of prejudice and hostility that encouraged them to congregate. However, arguments have been made that the residential concentration seen with these groups is not necessarily an indication of social segregation. In various aspects of their lives, particularly work, the immigrants mixed with other ethnicities. The studies reviewed here have pointed to the importance of considering the local scale and daily lived experiences when attempting to understanding ethnic relations.

These historical studies point to the social and economic advantages of clustering by recent immigrants, to provide support in a familiar linguistic, religious and familial environment. In modern times, labour demands of the receiving country are geographically specific, and housing available to immigrants is often concentrated in the poorest inner-city areas shunned by the indigenous population. All these factors promote clusters of immigrant families.

Over time, immigrant families and their offspring have generally dispersed from original settlement areas of poor housing as the labour and housing markets allow 
many to find better living conditions. Where cultural practises and beliefs remain strong, and especially where these dictate marriage within a restricted community, clusters remain but are more dispersed in the style of a mosaic. Peach (1996a) has also distinguished voluntary clustering due to cultural affinities and forced segregation due to housing and other discrimination.

At first sight, the historical view of immigrant dispersal from clusters may seem to be at odds with the increase in residential concentrations of particular ethnic groups measured by segregation indices in recent years. This paper offers a paradigm within which the paradox of growing concentrations and dispersal can be accommodated. It is primarily a demographic view that sees segregation as the result of a balance of natural population growth among young populations on the one hand and migration away from settlement areas on the other hand. Residential segregation therefore cannot be addressed directly as responsive to social policy or individual behaviour, but can be monitored and predicted and sometimes influenced via either of its two components: natural growth and migration.

The paper provides a discussion of this dynamic paradigm in the next section, suggesting the hypotheses by which it can be verified and developed. The remaining sections of the paper describe a case study of population dynamics in two Northern English towns, describing in turn the context, the data and methods used, and the results relating to population, housing and social change in the 1990s. A discussion both of the case study and of the potential benefits to planning and public policy of this demographic approach to racial composition also explores its limitations.

\section{Hypotheses}

Here the demographic consequences of immigration are proposed to the extent that they affect the ethnic composition of local areas. The first four hypotheses suggest rapid population growth leading to greater isolation and segregation. The next six suggest a subsequent counter-current of dispersal. The final hypotheses explore the nature of that dispersal with a focus on population, housing and workforce indicators of importance to regional planning. In each case a short explanation precedes the hypothesis which is deliberately phrased in a testable but general way, allowing for further hypotheses of greater nuance. While this paper is focused on quantitative evidence, interview methods, ethnographic and other qualitative approaches have much to offer elucidation of the processes suggested by each hypothesis.

\section{Hypotheses of population growth}

The role of labour shortages in specific industrial and geographical sectors in creating pioneer migrants suggests the first demographic expectation:

1. Pioneer immigration results in settlement areas of ethnically similar population

A distinction between immigration of pioneers and those that follow allows further influences on immigration to be explored. Continued clustering of ethnically similar residents is to be expected as a result of the attraction to new immigrants of people who are culturally familiar and supportive; they can provide the social and economic capital necessary to survive in foreign conditions after the demand for labour has ceased to be strong. The definition of 'ethnically similar' is a matter for empirical research. Chain migration (following in pioneer footsteps) and family building (joining spouses) may bring new immigrants from areas much closer to the origins of 
pioneers than ethnic categories used in official data collection can distinguish (specific Caribbean islands, Indian and Pakistani regions; for example, Ballard 1994).

2. Subsequent immigrants are attracted to existing clusters of population ethnically similar to themselves.

The young age structure of migrants suggests relatively few deaths. But generally one would expect that:

3. Settlement areas grow rapidly from relatively few deaths compared to the number of births.

The balance of new immigration and natural growth depends on many factors, including the legislative permission for spouses to join pioneer immigrants. With time the number of potential spouses within the group expands in the host country, so that the pressure for immigration of spouses decreases even when endogamous marriage (within the same group) is important. In general one might expect that:

4. Natural growth (births exceeding deaths) becomes greater than the net impact of migration.

This sequence of pioneer immigration of young workers, chain immigration and family building leads one to expect rapid population growth in geographic clusters. One would expect as a consequence increased concentration of ethnic or racial minorities in relation to the existing population.

\section{Hypotheses of dispersal}

The impact of growth on the existing population depends initially on the availability of local housing. The immediate likelihood is a reduction of in-migration to the area from other parts of the country. This may explain the loss of White population as much or more than the much-claimed and little-researched 'White flight'. Many hypotheses could be coined to investigate this phenomenon, which can be summarised as:

5. Natural growth limits the in-migration of all groups to immigrant settlement areas.

The following hypotheses are limited to the population dynamics of the minority population. As an immigrant population becomes a significant clustered ethnic minority through its natural growth, the local housing is insufficient for the needs of all its members. To some extent it is a matter simply of too few dwellings for the population. But economically successful families will also be able to seek better housing conditions. Both the physical limits and the economic attraction are reflected in an expectation that:

6. Pressure on housing leads to dispersal from settlement areas to other parts of the country (internal migration).

However, the distinction between simple insufficiency of dwellings and more complex social stratification leads to an expected relation between the distance and social nature of migration:

7. Internal migration to areas neighbouring the settlement areas is of residents with similar employment and housing conditions.

8. Internal migration further afield is of economically more successful members of the ethnic group.

Religious and cultural facilities and more simply family and social contacts shape the destination of migration, both in terms of creating new clusters, and in maintaining proximity to large concentrations that support greater facilities.

9. Internal migration maintains clusters of ethnically similar population, albeit in new locations. 
10. Migration away from the settlement areas is to destinations relatively close to the same or other settlement areas.

Hypotheses of socio-demographic change

Thus far, the posited combination of natural growth and dispersal could explain the continued high indices of segregation in spite of movement away from settlement areas. The next set of hypotheses consists of corollaries concerning sociodemographic indicators which are of particular importance to educational, housing and economic planning. They concern divergence between first and second generation minority populations, and convergence between diverse populations over time. They are frequently the subject of speculation and assumption in social forecasting and in regional development plans.

Fertility of immigrant populations is often high, partly due to the fact of family building taking place in the same period for most of the young immigrant workers of the same origin, and partly due to the higher expectations of family size in countries of origin. Over time one would expect a greater spread of family stages within the minority population and a growing proportion of women born and educated locally. Whether in the longer term fertility rates converge or remain different from those of the indigenous population is less predictable and may depend on employment and education trends as well as cultural preferences. In general, one would expect:

11. Fertility rates decline after the initial immigration period.

Housing pressure in pioneer immigrant settlement areas may create the conditions for households sharing the same housing units. In Britain there is a relatively high proportion of extended households of two or more related families in the Indian, Pakistani and Bangladeshi populations, and a higher proportion of single-adult households in the Caribbean population. A key assumption for housing plans is the extent to which current extended households are led by economic necessity and therefore represent hidden demand for smaller housing units; the alternative of cultural preference would represent continued demand for larger housing units. This leads to the following hypotheses:

12. Household formation differences between groups are persistent over time

13. Household formation differences between groups are persistent outside immigrant settlement areas

A similar argument may be made regarding the commonly very low economic activity among Muslim women in Britain, which may or may not change as the composition of the Muslim population becomes largely born and educated in Britain. Men among the Muslim populations also have relatively low economic activity. Each of the following hypotheses requires empirical testing with different outcomes to be expected for different minorities, men and women, and quite possibly for different locations:

14. Economic activity differences between groups are persistent over time.

15. Economic activity differences between groups are persistent outside immigrant settlement areas

These hypotheses address broad socio-demographic indicators of labour and housing development as they may be affected regionally in the medium and long-term by immigration. Similar hypotheses would be developed straightforwardly for other indicators of importance to broader health and community development. They form an agenda for quantitative research of importance to planning. Qualitative research has the capability to both support and explain the political and socio-cultural causes of 
change. As a bye-product such research will provide a greater understanding of ethnic composition and its development.

\section{Case study: Oldham and Rochdale in northern England}

The next three sections describe a study of two Metropolitan Districts in northern England which quantitatively address many of the hypotheses proposed above.

Rochdale and Oldham are neighbouring Districts to the north-east of Manchester. The two Districts are typical of towns outside London which received immigrants in the second half of the twentieth century. Along with many towns across Lancashire and Yorkshire, the local textile industry responded to international competition in the 1950s by expanding factory operating hours and recruiting to fill the extra overnight shifts. Recruitment was often from rural areas of Pakistan, including what is now the country of Bangladesh. The move did not save the textile industries from major decline, but gave impetus to immigration in the 1960s and 1970s to many northern towns of Britain. In 2001, each District's population was a little over 200 thousand. Each included between thirteen and sixteen thousand people with family origin from Pakistan, significant populations from Bangladesh, and smaller populations from India and the Caribbean (Table II). The total population with ethnic group recorded other than White in 2001 was thirty thousand in Oldham and twenty-three thousand in Rochdale. Immigration continues from Pakistan and Bangladesh at the rate of approximately four hundred per annum according to the local monitoring by the two local government councils. In both Districts about half of the populations of Pakistani and Bangladeshi origins were born in the UK.

\section{[Table II about here]}

The population pyramids of Figure 1 show the young age structure of the Pakistani and Bangladeshi groups. Cohorts aged under twenty are double the size of those aged over thirty, and relatively few are aged over seventy. Male pioneer immigrants are now aged in their sixties, somewhat older than their wives. This young age structure of both populations is the source of population growth as discussed below.

[Figure 1 about here]

Oldham had been one of three northern towns affected by destructive disturbances in the summer of 2001 in which mainly Asian young people confronted police (Kundnani 2001) and which official concerns blamed partly on concentrations of Asian population (Cantle 2001; Denham 2001; Ouseley 2001). When the Rochdale and Oldham Housing Market Renewal programme was awarded £54m in 2004 to pave the way for major housing development, it was concerned to develop housing in ways that would enhance community cohesion and reduce isolation of all communities. The programme prioritised thirty-one Housing Market Renewal (HMR) neighbourhoods for improvement. It wished to know how the ethnic composition of the two districts and neighbourhoods could be predicted to change. Work commissioned by the programme together with the two local government councils (Simpson and Gavalas 2005) forms the basis of the current paper.

In the case study the hypotheses outlined earlier were tested using results from the 1991 and 2001 censuses. 


\section{Data and methods}

By far the most complete datasets referring to the 'ethnic group' of individuals and the head of each household are the 1991 and 2001 Censuses. Individual data are not disclosed but are made available as cross-tabulations of ethnic group categories with age structure and social indicators. All the data were available for the two Districts as whole and further subdivided for the small 'output areas' from each census. Considerable estimation was required firstly to make the geography, ethnic group categories and other detail compatible between 1991 and 2001 datasets, and secondly to estimate the impact of migration between the two censuses separately from natural growth. This estimation is described briefly here and more fully in Simpson and Gavalas (2005).

The HMR neighbourhoods and current electoral ward boundaries (which had been revised since the 2001 census) were the 'targets' for census data. Data from the smallest census output areas were allocated to the target areas on a 'best fit' basis (in Oldham) and proportionally to the estimated number of households overlapping each source census area and the target boundaries (in Rochdale). This geographical data conversion adds only a little noise to the data because the small size of census output areas relative to the target areas ensures a high degree of fit (Simpson 2002). The two great advantages of data conversion are the resulting comparability over time and the use of areas of political currency at the time of the report. Here we report on the results for HMR neighbourhoods, and discuss the few conclusions which are further nuanced by analysis of electoral wards.

While ethnic group categories were used in both censuses, the question had changed. Fortunately for this study, the categories of White, Indian, Pakistani and Bangladeshi have been shown to have greatest stability over the period 1991 to 2001 (Platt, Akinwale and Simpson 2005; Simpson and Akinwale, forthcoming). Caribbean, African and Other Black were aggregated into a single 'Black' category. All other categories were aggregated to a residual 'Other' category to complete the six categories used in this study. Where output from the 1991 census amalgamated Indian, Pakistani and Bangladeshi, the same three groups were aggregated from 2001 Census output and labelled 'Asian'.

The detail available for the smallest census output areas is sufficient to explore many hypotheses, even though further restricted by the requirement to compare 1991 and 2001. For each broad ethnic group (White, Black, Indian/Pakistani/Bangladeshi, Other) it includes the number and proportion of households without a car, with no-one in employment, and in each of four tenure categories. It provides an age-breakdown for those aged under 5, 5-15, 16 to pensionable age, and of pensionable age, which further allows analysis of the average number of children and adults per household.

The population not represented in the census output - 'undercount' - was relatively small - estimated to be $0.6 \%$ in 2001 and $0.9 \%$ in 1991 for both Districts. It is likely to vary between ethnic groups, between geographical areas and between 1991 and 2001. The results must be considered approximate to the extent that they may be affected by errors in census output. In general, social inequalities are likely to be under-estimated by published census data (Simpson and Dorling 1994). The interpretation highlighted in this paper focuses on significantly large trends and differences that are very unlikely to be threatened by the quality of the data. 
To improve the evidence available directly from the census, the net impact of migration over the ten year period 1991-2001 has been estimated for each ethnic group. Migration is measured directly in the UK Census only from its question regarding address one year before the census. For small areas this is limited to a dichotomous categorisation of ethnic group (White and all Others for the year 20002001). The net impact of migration within the UK and the total migration from outside the UK is available in this way for each HMR neighbourhoods and current electoral ward. The extra ethnic group detail has been derived by estimating the births and deaths during the period 1991-2001 for each ethnic group, and deducting this natural population change from the overall population change indicated by the census (The appendix gives the details of this standard demographic approach which we applied in a novel way to ethnic group populations).

\section{Results: population, household and social change}

\section{Population change, areas of Asian settlement and areas of Asian growth}

The demographic approach outlined earlier suggests overall growth of the immigrant populations in Oldham and Rochdale. If original settlement areas have become insufficient for that growth, movement from them to nearby areas is to be expected such that the immigrant-origin populations in those nearby areas will have grown at a proportionately higher rate than in the settlement areas. Figure 2 shows a classification of each HMR area of Oldham and Rochdale, based on census statistics of the ethnic composition of the area in 1991 and the growth of the Asian population in the following ten years. Table III shows those statistics for the aggregated areas in each class. Its first two columns provide the definition of each class.

[Figure 2 about here]

\section{[Table III about here]}

The settlement HMR areas all had more than 33\% Asian population (Indian, Pakistani and Bangladeshi together) already in 1991. The choice of this threshold to classify settlement areas was not arbitrary: in the case of electoral wards, all other areas had less than 10\% Asian population in 1991. HMR areas were somewhat less clearly separated due to their variation in total population but the naming of such areas was recognised as valid by research staff in the two Districts. The other areas are divided according to the growth of the Asian population during the decade, into areas of large Asian population growth (more than 500 residents), small Asian population growth (100 but not as much as 500 , and the remaining areas with smaller Asian population growth. Again the classification was not arbitrary but based on examination of each area's statistics to provide most discrimination between the classes of area, as is possible with the relatively small total number of areas involved. The total population of each class of area is of similar order, varying from 26 thousand to 60 thousand people.

There are two conclusions that can be drawn immediately from Figure 2 and Table III. First, the percentage growth of the Asian population is considerable in each type of area, but is much greater outside the settlement areas. Second, that growth is not evenly spread. Settlement areas are not a single block, and growth areas are not all those contiguous to the settlement areas. Thus the movement is not even, in the image 
of a fountain spreading water outwards, but some areas are more attractive than others, giving rise to the clustered mosaic pattern observed by Peach (1996b).

Thus the population change is consistent with the growth and clustered dispersal expected from our earlier discussion. However, this pattern of population change cannot distinguish the extent to which the change is movement from settlement areas to other areas, or differing rates of natural growth. We examine this in the next section from direct measures of migration from the 2001 Census, and from indirect estimates of both migration and natural change.

\section{Migration and natural population change}

Table IV shows the migration data available from the 2001 Census tabulations, for each type of area, which measures the impact of migration in the year before the Census within the UK, and of immigration from overseas, for White and for the total of all other ethnic groups. Emigration, out of the UK, cannot be captured by a national census. The statistics throw light on some of the hypotheses discussed earlier.

\section{[Table IV about here]}

First, there is migration out of settlement areas to other parts of the UK, in net terms. This is the case for both White and other groups taken as a whole, which in these areas are mainly Pakistani and Bangladeshi, and amounts to between 2\% and $3 \%$ of the 2001 population in the single year before the census, 2000-2001. For the non-White populations, there is clearly dispersal from the settlement areas to the other types of area. The net gain is greatest in percentage terms into the areas of 'small' Asian population growth. These may be the areas of greater absolute growth in future years.

The White net movement out of the settlement areas is not much greater in percentage terms than other ethnic groups, but it is not mirrored by growth in the other types of area. The movement is to areas further away. In fact the loss of White population from Oldham and Rochdale Districts as a whole was a little under 1\%, and is not greater than from many other Districts in England with very few residents of other ethnic groups. It is thus consistent with a general migration from cities to less urban areas, usually termed counter-urbanisation. There is no evidence for 'white flight' from these Districts.

As one would expect, the impact of immigration from outside the UK is higher in percentage terms for the Asian population (around 1\%) than for the White population (around 0.1\%). However immigration has a similar impact on the non-White population in each type of area in terms of the percentage addition to the population.

This analysis is limited to two very broad ethnic categories, to the single year before the Census, and does not show the impact of natural growth from an excess of births over deaths. These limitations are overcome in Table V. It is derived as described in Appendix 1, where it is shown that the estimates are probably conservative in their magnitude but correct in the net direction (positive or negative) of migration and natural change. Note that the net impact of migration in Table $\mathrm{V}$ includes emigration, but does not distinguish between migration within the UK and migration overseas. It refers to the whole ten-year period between the last two censuses, and to each of six ethnic groups.

[Table $\mathrm{V}$ about here] 
The growth of the populations of Pakistani and Pakistani origins as a whole has a considerable contribution from both natural change and migration. More than two thirds of that growth during the 1990s was from natural change: overall some nine thousand residents compared to four thousand from migration. Oldham and Rochdale are already at the stage of demographic development where natural change has a greater role than migration, in overall terms. However, the population dynamics are different in each type of area. In settlement areas, population growth is almost entirely from natural change, as one would expect from the young age structure of the population. In contrast, in areas of growth of the Pakistani and Bangladeshi populations, the impact of migration is similar and usually greater than that of natural growth.

Although the statistics do not show the origin and destination of the migration, it is safely assumed that there is significant dispersal from the settlement areas to the areas of population growth. The simultaneous growth and dispersal hypothesised earlier is evident in Oldham and Rochdale. In the settlement areas, there is an overall loss of Pakistani population from migration. This includes immigration from overseas, such that the dispersal within the UK to other areas can be seen to be that much larger.

The detailed figures for each area show that the same is true for the smaller Bangladeshi population. Its own settlement area is just a part of the class of Asian settlement areas used here, and movement of the Bangladeshi population is away from that area, to other areas within that class as well as further afield.

The negative natural change for the White population between 1991 and 2001 shows that there were more deaths than births. This is consistent with White families not moving to the areas of Asian settlement and for those remaining White families to be of relatively older composition.

\section{Household formation}

In Britain, housing policy assumes the need for a mix of types of housing based on the distribution of sizes and types of household observed in the population as a whole. Previous studies have shown the propensity for larger families and extended households of adult siblings and three generations in the Indian, Pakistani and Bangladeshi populations (Murphy 1996; Simpson and Close 1996). The Housing Market Renewal programme of Oldham and Rochdale needed to foresee whether those different housing demands will affect the future needs of those Districts as the proportion of Asian households grows, or whether household formation might tend towards smaller households for Pakistani and Bangladeshi residents having lived longer in Britain, and those living away from the original settlement areas.

The average number of adults in a household is key to housing demand, as children as a rule do not live on their own. Figure 3 shows the changing household size for the four types of area between 1991 and 2001. The scale is the average number of persons per household. The upper lines show the average household size including children, while the lower lines show the average number of adults (all persons aged 16 or older) per household. The gap between them is the number of children aged under 16 per household ${ }^{1}$.

[Figure 3 about here]

Figure 3 shows that White households have very similar average household structure in each type of area. The average number of adults has decreased slightly between 1991 and 2001, probably due to more households of one adult. The number 
of children on average in each household has remained steady. It is well below one because many White households do not have any children.

The average number of adults in Asian households (the data do not allow a comparison over time for Pakistani and Bangladeshi separately) is higher than for White households, reflecting the lower incidence of single-person households and the higher proportion of extended families. It has not reduced since 1991, indeed if anything it has slightly increased (the contrary trend for the 'Other areas' is based on a small number of households, and is not replicated for the classification of electoral wards not shown here). However the number of children in each household on average has reduced over time, and is lower outside the areas of Asian settlement. Although this is not a direct measure of fertility, it does suggest that the fertility rates of these immigrant-origin populations have decreased over time and are lower in the second generation, as suggested earlier and supported by other studies (Sporton and White, 2002; Coleman, 1994).

The need for larger housing units is determined mainly by the number of adults in a household, which is not reducing in the Asian populations. To avoid overcrowding, larger units of housing are needed, although correspondingly fewer units for the same population size. This lack of convergence with White household structure is not surprising when considered alongside other research which shows the continuing prevalence of extended families in the Indian population in Britain, which has a longer residence and more prosperous employment outcomes than the Pakistani and Bangladeshi populations (Murphy 1996; Simpson and Close 1996).

\section{Social and employment characteristics}

We are now able to examine whether those individuals and families who now live in the new areas of South Asian population have improved their conditions either between 1991 and 2001 or in comparison areas of settlement. Table VI shows the three indicators which are available from both censuses. In 2001 the information is available for each ethnic group, while in 1991 the broad 'South Asian' was used, including the Indian group as well as Pakistani and Bangladeshi populations. The tables now refer to households and subgroups of the population. In order to focus on the larger sub-populations for which the data is most reliable, Table VI shows White, Pakistani and Bangladeshi groups, and the areas of settlement and greatest South Asian population growth.

\section{[Table VI about here]}

A number of conclusions relevant to the earlier hypotheses can be made. Poor labour market outcomes are common for the Pakistani and Bangladeshi populations. Unemployment in 2001 was more than double that of the White population in the same areas. Overcrowding is also severe for both populations in 2001, affecting between a quarter and a half of households in each type of area. Car ownership is often used in Britain to measure the general level of wealth of a population, even though car ownership can be a lifestyle choice for some individuals. There are still many households without a car. In Oldham and Rochdale, the Pakistani households tended to have access to a car in spite of the lower incomes indicated by the level of unemployment.

However, conditions for all populations have improved during the 1990s. Unemployment and overcrowding decreased, at a faster pace for the Pakistani and 
Bangladeshi populations than the White population, even though not sufficiently to make the conditions similar in the three groups.

The differences between areas of settlement and areas of growth are not noticeable. Only overcrowding is consistently a little less in the growth areas for both Pakistani and Bangladeshi populations, perhaps reflecting the smaller families that were noted above.

Table VII shows the tenure of each type of area. Home-ownership has decreased since 1991 for the Asian populations as a whole by 13 percentage points. It is relatively high only for the Pakistani population, where it averages $67 \%$ across all the HMR neighbourhoods. Private renting is more common for both the Pakistani and Bangladeshi populations than the White population. Renting from a social landlord is concentrated outside the local government (Council) sector, in contrast to the White population where local government provision has been historically common.

\section{[Table VII about here]}

In summary, the social and employment conditions in areas of South Asian growth are similar to those of the settlement areas. The movement away from settlement areas within Oldham and Rochdale appears to be a response to the limited capacity of housing in those areas, and not motivated by improved resources. The areas of growth can be seen as overspill areas of similar conditions. There are however fewer owneroccupiers in those areas among the Pakistani and Bangladeshi populations, with more reliance on all types of rented property. Affluent movement away from the settlement areas is not evident, but may be to areas outside the two Districts, or to areas where the Pakistani and Bangladeshi populations are much smaller.

\section{Discussion}

The evidence from Oldham and Rochdale provides strong confirmatory evidence of the co-existence of growth and dispersal of populations of recent immigrant origin. It measures clear characteristics of these two processes. There are significant clusters of Asian population in areas of original settlement of pioneer immigrants. Currently immigrants are attracted to those areas in greater numbers than other areas, but not greater in proportional terms. Those settlement areas have a relatively young age structure, with few deaths relative to the number of births, and have grown rapidly for this reason. This natural growth now exceeds the growth from immigration by a factor of two. There has been migration out of the settlement areas such that the Asian population is growing at a considerably faster rate in other areas, which are close to the settlement areas but do not include all the neighbouring areas. These growth areas are similar in employment conditions to the settlement areas, although much improved in all areas over the decade 1991-2001. This study did not identify significant clusters of more prosperous families. Fertility rates have declined over time and are lowest outside the settlement areas, but household structures (of extended families) have been maintained over time and space.

The hypotheses presented in this paper predict the medium and long-term demographic consequences of immigration and provide a framework that makes sense of local population change. The framework adds considerable richness to tracking segregation indices over time, which ignores the powerful natural demographic change that develops after immigration. Indeed, it suggests that segregation should be expected to increase for a period after pioneer immigration due to growing 
populations and a spatial expansion of noticeable clusters of immigrant-origin families. Cultural facilities attract particular groups, creating spatial and cultural fission along caste, regional, and sectarian lines (Dahya 1974). The framework suggests that growing concentrations are likely to continue for some decades, until the age structure stabilises and dispersal becomes the main feature, accompanied by a reduction in segregation indices.

These predictable demographic trends toward larger concentrations of Asian residents at the same time as dispersal challenge the assumption that concentration is a form of voluntary segregation and must be viewed negatively. It is a result mainly of natural growth, which is not easily amenable to policy change.

Although, the data in Britain are limited in their time frame and the coarseness of their ethnic categories, they have immediate useful impact on local planning. Once the predictable dynamics of population change are understood, planning can focus on what is amenable to policy influence. Scenario-building by the local Councils of Oldham and Rochdale are focused on the development of equality of housing and employment opportunity. For example, the Housing Market Renewal programme is encouraging migration of Asian families to areas beyond the inner town areas; the Councils have had success in a scheme for the community induction of new families of whatever origin on housing estates, encouraging interaction and participation while sanctioning hostile or racist receptions when they occur (HMR Board 2005). The demographic data for small areas allow scenario-building to evaluate policy alternatives, and can be the basis for qualitative research on young people's aspirations and expectations.

There is plenty of scope for similar work in other areas, but also for extension of the hypotheses and their testing. Qualitative surveys following Debbie Phillips (2005) are needed to test the relationship between spatial geography and integration into the housing and labour markets, as well as the role of institutions in easing integration. Quantitative studies should divert energy from the 'industry' that measures segregation into a more historical and dynamic view of change. Such studies should look where possible directly at gross flows of migration of different groups including Whites, at the distance of migration, and at the social stratification that results from migration of the more prosperous. If levels of segregation remain of interest, demographic projections would provide a useful prognosis. In European countries, White immigrants from Eastern Europe are the 'new blacks' of the early 21st century, whose demographic development may be followed in the same way as outlined in this paper.

In this paper we have presented a framework which can be used positively, not to stigmatise areas according to their racial composition but to understand the rapidly changing population of our cities and to plan for a future of integration and equality.

Acknowledgements - the case study was funded by Oldham and Rochdale Metropolitan Borough Councils (on behalf of the Oldham Partnership and Rochdale Interagency Information Group respectively) and the Rochdale and Oldham Housing Market Renewal programme. These organisations manipulated census data into the area boundaries used in this study and gave regular helpful feedback on the study. The content of this paper is entirely the responsibility of the authors. Paul Norman provided Figure 2. 


\section{Appendix: estimation of net migration 1991-2001 by ethnic group}

While there has been discussion of including ethnic group at birth and death certification in the UK, the moral and political case for doing so has not yet been successfully argued. Health service records of births have included ethnic group but are incomplete for the period 1991-2001 in Oldham and Rochdale.

We have here estimated the number of births and deaths during the 1991-2001 period, as a means of separating their influence on population change from the net impact of migration. This is a standard demographic approach to indirectly estimate migration, but is more rarely applied to ethnic groups.

We have taken the 2001 census population aged under 10, all of whom will have been born in the period 1991-2001, and scaled it to be consistent with the total number of births in that period.

For each HMR neighbourhood or electoral ward $\mathrm{i}$ :

(Births 1991-2001) ${ }_{i}=\underline{\text { (Children aged 0-9 in 2001) }} i *$ (District births 1991-2001)

(District children aged 0-9 in 2001)

The children aged 0-9 in each area were estimated from 2001 census output (Theme Table 3) as those aged $0-4$ together with $5 / 11$ of those aged 5-15. Each District's total births were taken from the Office for National Statistics population estimates series.

We have applied England and Wales mortality rates to the population in 1991, and scaled the result to be consistent with the total number of deaths during 1991-2001.

For each HMR neighbourhood or electoral ward i, the survival rate is used for each age group that appears in the small area census statistics for 1991; summing over all ages gives an initial estimate of deaths:

(Initial estimate of deaths) ${ }_{i}=$

$\sum\left[\left(\right.\right.$ Population age $a$ in 2001) ${ }_{i} *(1-$ national 10-year survival rate for age $\left.a)\right]$ Then

(Deaths 1991-2001) ${ }_{i}=\underline{\text { (Initial estimate of deaths) }} i *$ (District deaths 1991-2001)

(District Initial estimate of deaths)

The ten year survival rate for age group $\mathrm{x}$ to $\mathrm{x}+\mathrm{n}$, is taken from a life table for England and Wales, for 1998, available at www.mortality.org, and can be expressed as $\frac{{ }_{n} L_{x+m}}{L_{x}}$, with $\mathrm{m}=10$. An adjustment is required for the final open-ended age group.

The 1991 age structure is taken from the 1991 census (Table S06).

The net impact of migration during the period 1991-2001 is the subtraction of natural change from total population change.

For each HMR neighbourhood or electoral ward i, $(\text { Net migration })_{i}=\left[(\text { Population 2001 })_{i}-(\text { Population 1991 })_{i}\right]$

- [(Births 1991-2001) ${ }_{i}-$ (Deaths 1991-2001) $\left.i\right]$

Our methods estimate the net direction of migration correctly, but may underestimate its size, because we have not taken into account the births and deaths to migrants. Where net migration is inwards, our methods slightly over-estimate births because some young children of 2001 were born elsewhere; similarly deaths are under-estimated because some in-migrants during the period also die. In that case we would over-estimate natural change and under-estimate net in-migration. On the other hand, if there has been net out-migration, the same logic shows that we will underestimate the size of that net out-migration. 
Thus the method correctly identifies the direction of the net impact of migration inwards or outwards - but is conservative in the estimation of its magnitude. 


\section{Notes}

1 The census allows calculation of average household size for an ethnic group as the ratio of the number of people of the ethic group divided by the number of heads of household of that group ('household reference persons' in the terminology of the UK 2001 Census). In general this would not be appropriate where there are many households of people of different ethnic groups, or where the population not in households was significantly large. Neither of these potential limitations are a concern in this study.

\section{References}

Ballard R ed 1994 Desh Pardesh: the South Asian presence in Britain Hurst \&Co, London

Bradford Council 1997 Household forecasts for Bradford District 1996: documentation City of Bradford Metropolitan District Council, Directorate of Corporate Service Strategic Management Unit, Research Section, Bradford

Busteed M A Hodgson R I and Kennedy T F 1992 The myth and reality of Irish migrants in mid- $19^{\text {th }}$ Century Manchester: a preliminary study in O'Sullivan P ed The Irish in the New Communities Leicester University Press, Leicester/London 26-51

Busteed M A 2000 Little Islands of Erin: Irish Settlement and identity in MidNineteenth-Century Manchester in MacRaild D M ed The Great Famine and Beyond. Irish Migrants in Britain in the Nineteenth and Twentieth Centuries Irish Academic Press, Dublin 94-127

Cantle T 2001 Community Cohesion: a report of the Independent review Team Home Office, London.

Coleman D 1994 Trends in fertility and intermarriage among immigrant populations in western Europe as measures of integration, J. Biosoc Sci, 26 107-136

Dahya B 1974 The nature of Pakistani ethnicity in industrial cities in Britain, in Cohen A ed Urban ethnicity Tavistock, London

Denham J 2001 Building cohesive communities: a report of the ministerial group on public order and community cohesion Home Office, London

Dorling D 2005 Why Trevor is wrong about race ghettos The Observer 25 September 14-15

Duncan O D and Duncan B 1955 A methodological analysis of segregation measures American Sociological Review 20 210-217

Fortuijn J D Musterd S and Ostendorf W 1998 International migration and ethnic segregation: impacts on urban areas Urban Studies, 35 367-370

GLA 2005 London's changing population: diversity of a world city in the $21^{\text {st }}$ century DMAG briefing 2005/39, Greater London Authority, London

Gwynn R 1985 Huguenot Heritage: The History and Contribution of the Huguenots in Britain Routledge/Kegan Paul, London

Gwynn R 2002 Huguenot Heritage: The History and Contribution of the Huguenots in Britain $3^{\text {rd }}$ Ed. Routledge/Kegan Paul, London 
Hintermaier J M 2001 The First Modern Refugees? Charity, Entitlement, and Persuasion in the Huguenot Immigration of the 1680s' Albion 32 429-449

HMR Board 2005 The role of HMR in relation to community cohesion. Report to the Rochdale and Oldham Housing Market Renewal Board, $6^{\text {th }}$ June HMR Board, Oldham

Johnston R, Forrest J and Poulsen M 2002 The ethnic geography of EthniCities Ethnicities 2 209-235

Kantrowitz N 1981 Ethnic segregation: social reality and academic myth in Peach $\mathbf{C}$ Robinson $\mathbf{V}$ and Smith $\mathbf{S}$ eds Ethnic segregation in cities London, Croom Helm 43-57

Kundnani A 2001 From Oldham to Bradford: the violence of the violated, Race and Class 43 105-110

Lieberson S 1963 Ethnic Patterns in American Cities The Free Press of Glencoe, New York

MacRaild D M 1999 Irish Migrants in Modern Britain, 1750-1922 Macmillan, Basingstoke

Massey D S and Denton N A 1989 Hypersegregation in U.S. Metropolitan areas: Black and Hispanic segregation along five dimensions. Demography $26373-393$

Murphy M 1996 Household and family structure among the ethnic minority groups in Britain in Coleman $\mathbf{D}$ and Salt $\mathbf{J}$ eds Ethnic minorities in Britain: general characteristics Office of Population Censuses and Surveys, London

Neal F 2000 The Foundations of the Irish Settlement in Newcastle upon Tyne: The Evidence in the 1851 Census in MacRaild D M ed The Great Famine and Beyond. Irish Migrants in Britain in the Nineteenth and Twentieth Centuries Irish Academic Press, Dublin 71-93

Newman D 1985 Integration and Ethnic Spatial Concentration: The Changing Distribution of the Anglo-Jewish Community Transactions of the Institute of British Geographers 10 360-376

Ouseley H 2001 Community pride not prejudice, making diversity work in Bradford Bradford Vision, Bradford

Peach C 1996a Good Segregation, Bad Segregation Planning Perspectives 11 1-20

Peach C 1996b Does Britain have ghettoes? Transactions, Institute of British Geographers 21 216-235

Phillips D 2005 Parallel lives? Challenging discourses of British Muslim selfsegregation Environment and Planning D: Society and Space 35.

Phillips T 2005 After 7/7: Sleepwalking to segregation, speech to the Manchester Council for Community Relations, 22nd September, Commission for Racial Equality, London

Platt L Simpson L and Akinwale B 2005 Stability and response rates for ethnic group in the UK Census Population Trends 121 35-45 
Robinson V 1986 Transients, settlers, and refugees Oxford University Publishers, Oxford

Simpson L 2002 Geography conversion tables: a framework for conversion of data between geographical units International Journal of Population Geography 8 69-82

Simpson L 2004 Statistics of racial segregation: measures, evidence and policy Urban Studies 41 661-681

Simpson L and Akinwale B forthcoming Stability and change in ethnic group in England and Wales, Journal of Official Statistics.

Simpson L and Gavalas V 2005 Population dynamics within Rochdale and Oldham: population, household and social change Centre for Census and Survey Research University of Manchester, Manchester.

Simpson S and Close K 1996 Ethnicity and household headship rates from the 1991 Census: availability of national and local data CCSR Occasional Paper 11 University of Manchester, Manchester

Simpson S and Dorling D 1994 Those missing millions: implications for social statistics of non-response to the 1991 Census Social Policy 23 543567

Sporton D and White P 2002 Fertility in Haskey J ed Population projections by ethnic group a feasibility study Office for National Statistics Studies on Medical and Population Subjects no. 67, The Stationery Office, London 8192

Taeuber K E and Taeuber A 1965 Negroes in Cities: Residential Segregation and Neighborhood Change Aldine Publishing Co, Chicago

Valins 02003 Stubborn identities and the construction of socio-spatial boundaries: ultra-Orthodox Jews living in contemporary Britain Transactions of the Institute of British Geographers 28 158-175

Vigne R and Littleton C eds 2001 From Strangers to Citizens. The Integration of Immigrant Communities in Britain, Ireland and Colonial America, 1550-1750 The Huguenot Society/Sussex Academic Press, London/Brighton

Waterman S and Kosmin B A 1987 Residential patterns and processes: a study of Jews in three London boroughs Transactions of the Institute of British Geographers 13 79-95

Wilkes R and Iceland J 2004 Hypersegregation in the twenty-first century Demography 41 23-26

Zuberi T 2001 Thicker than blood: how racial statistics lie University of Minnesota Press, Minneapolis 
Tables and figures

Table I Minority population groups' concentration and dispersal in England

(a) Concentrations of non-White population 19912001

Electoral wards with non-White majority $57 \quad 118$

Proportion of all non-White residents who live in these areas $15 \% \quad 23 \%$

(b) Net impact of migration within UK, 2000-2001

Non-White White

118 Electoral wards with a non-White majority in 2001 $-14,716 \quad-9,747$ Source: Censuses 1991 and 2001. Tables L06, ST101, KS24. Electoral wards of England.

Table II Populations of Oldham, Rochdale, and England \& Wales

\begin{tabular}{lrrrrrrr}
\hline & \multicolumn{2}{c}{ Oldham } & & \multicolumn{2}{c}{ Rochdale } & & \multicolumn{2}{c}{ England \&Wales } \\
\hline Total persons & 217.2 & $100 \%$ & 205.2 & $100 \%$ & $52,041.9$ & $100 \%$ \\
\hline White & 187.1 & $86 \%$ & 181.9 & $89 \%$ & $47,520.9$ & $91 \%$ \\
Black & 1.2 & $1 \%$ & 0.6 & $0 \%$ & $1,139.5$ & $2 \%$ \\
Indian & 1.5 & $1 \%$ & 0.8 & $0 \%$ & $1,036.7$ & $2 \%$ \\
Pakistani & 13.6 & $6 \%$ & 15.8 & $8 \%$ & 714.8 & $1 \%$ \\
Bangladeshi & 9.8 & $5 \%$ & 2.6 & $1 \%$ & 280.9 & $1 \%$ \\
Other & 3.9 & $2 \%$ & 3.5 & $2 \%$ & $1,349.1$ & $3 \%$ \\
\hline Population in thousands in 2001, and per cent. Source: 2001 Census &
\end{tabular}

Population in thousands in 2001, and per cent. Source: 2001 Census 
Table III Area classification of Housing Market Renewal areas in Oldham and Rochdale according to South Asian population and growth

\begin{tabular}{|c|c|c|c|c|c|c|}
\hline & \multirow[b]{2}{*}{$\begin{array}{r}1991 \text { South } \\
\text { Asian } \\
\text { population, \% }\end{array}$} & \multicolumn{3}{|c|}{$\begin{array}{r}\text { 1991-2001 South Asian } \\
\text { population change }\end{array}$} & \multirow{2}{*}{$\begin{array}{r}2001 \\
\text { South } \\
\text { Asian } \\
\text { population }\end{array}$} & \multirow[b]{2}{*}{$\begin{array}{r}2001 \text { total } \\
\text { population }\end{array}$} \\
\hline & & $\begin{array}{c}\text { Number } \\
\text { in each } \\
\text { area }\end{array}$ & $\begin{array}{c}\text { Total } \\
\text { change, } \\
\mathbf{N}\end{array}$ & $\begin{array}{c}\text { Total } \\
\text { change, } \\
\%\end{array}$ & & \\
\hline Settlement & $>33 \%$ & & $+6,186$ & $+31 \%$ & 25,876 & 40,219 \\
\hline Growth & & $\geq 500$ & $+5,510$ & $+98 \%$ & 11,145 & 60,169 \\
\hline Small growth & & $\geq 100$ & $+1,134$ & $+249 \%$ & 1,590 & 25,902 \\
\hline Other & & $<100$ & +445 & $+75 \%$ & 1,035 & 46,551 \\
\hline All HMR areas & & & $+13,275$ & $+50 \%$ & 39,645 & 172,841 \\
\hline
\end{tabular}

Source: 1991 and 2001 Censuses. 
Table IV Migration 2000-2001, extract for HMR areas in Oldham and Rochdale

\begin{tabular}{|c|c|c|c|c|c|c|}
\hline & \multicolumn{3}{|c|}{$\begin{array}{l}\text { Net Migration within the UK } 2000- \\
2001, \% \text { of } 2001 \text { population }\end{array}$} & \multirow[b]{2}{*}{ All } & \multicolumn{2}{|c|}{$\begin{array}{l}\text { Immigration } 2000-2001, \\
\% \text { of } 2001 \text { population }\end{array}$} \\
\hline & All & White & $\begin{array}{c}\text { Groups other } \\
\text { than White }\end{array}$ & & White & $\begin{array}{c}\text { Groups other } \\
\text { than White }\end{array}$ \\
\hline Asian settlement 1991 & -2.2 & -2.6 & -2.0 & 0.7 & 0.2 & 1.0 \\
\hline Asian growth 91-01 & -0.7 & -1.5 & 2.4 & 0.5 & 0.2 & 1.3 \\
\hline Small Asian growth & -0.3 & -0.7 & 4.1 & 0.2 & 0.1 & 0.9 \\
\hline Other areas & -0.6 & -0.7 & 2.1 & 0.2 & 0.1 & 0.8 \\
\hline
\end{tabular}

Source: 2001 Census, Table KS24

Table V Natural change and net migration 1991-2001: extract for HMR areas in Oldham and Rochdale. Numbers of people

\begin{tabular}{|c|c|c|c|c|c|c|c|}
\hline & \multicolumn{7}{|c|}{ Natural change 1991-2001 } \\
\hline & $\begin{array}{r}\text { Total } \\
\text { persons }\end{array}$ & White & Black & Indian & Pakistani & $\begin{array}{r}\text { Bangla } \\
\text { deshi }\end{array}$ & Other \\
\hline \multicolumn{8}{|l|}{ Asian settlement } \\
\hline Asian growth 91-01 & 2442 & -812 & 17 & 43 & 2160 & 583 & 448 \\
\hline Small Asian growth & 795 & 302 & 9 & 3 & 233 & 122 & 126 \\
\hline \multirow[t]{3}{*}{ Other areas } & 885 & 382 & 5 & 14 & 168 & 46 & 269 \\
\hline & \multicolumn{4}{|c|}{ Net migration 1991-2001 } & & & \\
\hline & $\begin{array}{r}\text { Total } \\
\text { persons }\end{array}$ & White & Black & Indian & Pakistani & $\begin{array}{r}\text { Bangla } \\
\text { deshi }\end{array}$ & Other \\
\hline \multicolumn{8}{|l|}{ Asian settlement } \\
\hline 1991 & -4188 & -4454 & -300 & -358 & -211 & 741 & 392 \\
\hline Asian growth 91-01 & -3481 & -6599 & -164 & -56 & 1743 & 1037 & 555 \\
\hline Small Asian growth & 414 & -494 & -54 & 9 & 508 & 258 & 185 \\
\hline Other areas & -3253 & -3640 & -105 & -4 & 168 & 53 & 270 \\
\hline
\end{tabular}

Source: Derived by the authors as explained in the text. 


\begin{tabular}{|c|c|c|c|c|c|}
\hline & $\begin{array}{r}2001 \\
\text { White }\end{array}$ & $\begin{array}{r}2001 \\
\text { Pakistani } \\
\end{array}$ & $\begin{array}{r}2001 \\
\text { Banglade } \\
\text { shi } \\
\end{array}$ & $\begin{array}{r}\text { Change } \\
1991- \\
2001 \\
\text { White }\end{array}$ & $\begin{array}{r}\text { Change } \\
1991- \\
2001 \\
\text { Asian } \\
\end{array}$ \\
\hline & & \multicolumn{2}{|c|}{$\%$ unemployed } & \multicolumn{2}{|c|}{$\%$ point change } \\
\hline All HMR Oldham and Rochdale & 9 & 20 & 24 & -7 & -11 \\
\hline HMR Asian settlement 1991 & 10 & 21 & 23 & -7 & -13 \\
\hline HMR Asian growth 91-01 & 9 & 19 & 31 & -7 & -5 \\
\hline & \multicolumn{3}{|c|}{$\%$ households overcrowded } & \multicolumn{2}{|c|}{$\%$ point change } \\
\hline All HMR Oldham and Rochdale & 2 & 26 & 44 & -1 & -12 \\
\hline HMR Asian settlement 1991 & 2 & 29 & 47 & -1 & -10 \\
\hline HMR Asian growth 91-01 & 2 & 25 & 35 & 0 & -12 \\
\hline & \multicolumn{3}{|c|}{$\%$ households without car } & \multicolumn{2}{|c|}{$\%$ point change } \\
\hline All HMR Oldham and Rochdale & 49 & 33 & 56 & -9 & -13 \\
\hline HMR Asian settlement 1991 & 52 & 33 & 55 & -7 & -17 \\
\hline HMR Asian growth 91-01 & 52 & 32 & 60 & -8 & -4 \\
\hline
\end{tabular}




\begin{tabular}{|c|c|c|c|c|c|}
\hline & $\begin{array}{r}2001 \\
\text { White }\end{array}$ & $\begin{array}{r}2001 \\
\text { Pakistani } \\
\end{array}$ & $\begin{array}{r}2001 \\
\text { Banglade } \\
\text { shi }\end{array}$ & $\begin{array}{r}\text { Change } \\
1991- \\
2001 \\
\text { White } \\
\end{array}$ & $\begin{array}{r}\text { Change } \\
1991 \\
2001 \\
\text { Asian } \\
\end{array}$ \\
\hline & \multicolumn{3}{|c|}{$\%$ households owner-occupied } & \multicolumn{2}{|c|}{$\%$ point change } \\
\hline All HMR Oldham and Rochdale & 50 & 67 & 49 & 1 & -13 \\
\hline HMR Asian settlement 1991 & 51 & 72 & 55 & -4 & -10 \\
\hline HMR Asian growth 91-01 & 47 & 62 & 28 & 1 & -19 \\
\hline & \multicolumn{3}{|c|}{$\%$ rented from Council } & \multicolumn{2}{|c|}{$\%$ point change } \\
\hline All HMR Oldham and Rochdale & 29 & 8 & 13 & -9 & 0 \\
\hline HMR Asian settlement 1991 & 24 & 6 & 8 & -3 & -3 \\
\hline HMR Asian growth 91-01 & 32 & 10 & 33 & -11 & 5 \\
\hline & \multicolumn{3}{|c|}{$\%$ other social landlord } & \multicolumn{2}{|c|}{$\%$ point change } \\
\hline All HMR Oldham and Rochdale & 8 & 10 & 20 & 1 & 9 \\
\hline HMR Asian settlement 1991 & 11 & 10 & 21 & 0 & 9 \\
\hline HMR Asian growth 91-01 & 9 & 12 & 20 & 3 & 9 \\
\hline & & \multicolumn{2}{|c|}{$\%$ privately rented } & \multicolumn{2}{|c|}{$\%$ point change } \\
\hline All HMR Oldham and Rochdale & 11 & 14 & 18 & 7 & 6 \\
\hline HMR Asian settlement 1991 & 15 & 13 & 17 & 8 & 5 \\
\hline HMR Asian growth 91-01 & 12 & 15 & 21 & 8 & 6 \\
\hline
\end{tabular}


Figure 1 Population structure Oldham and Rochdale 2001
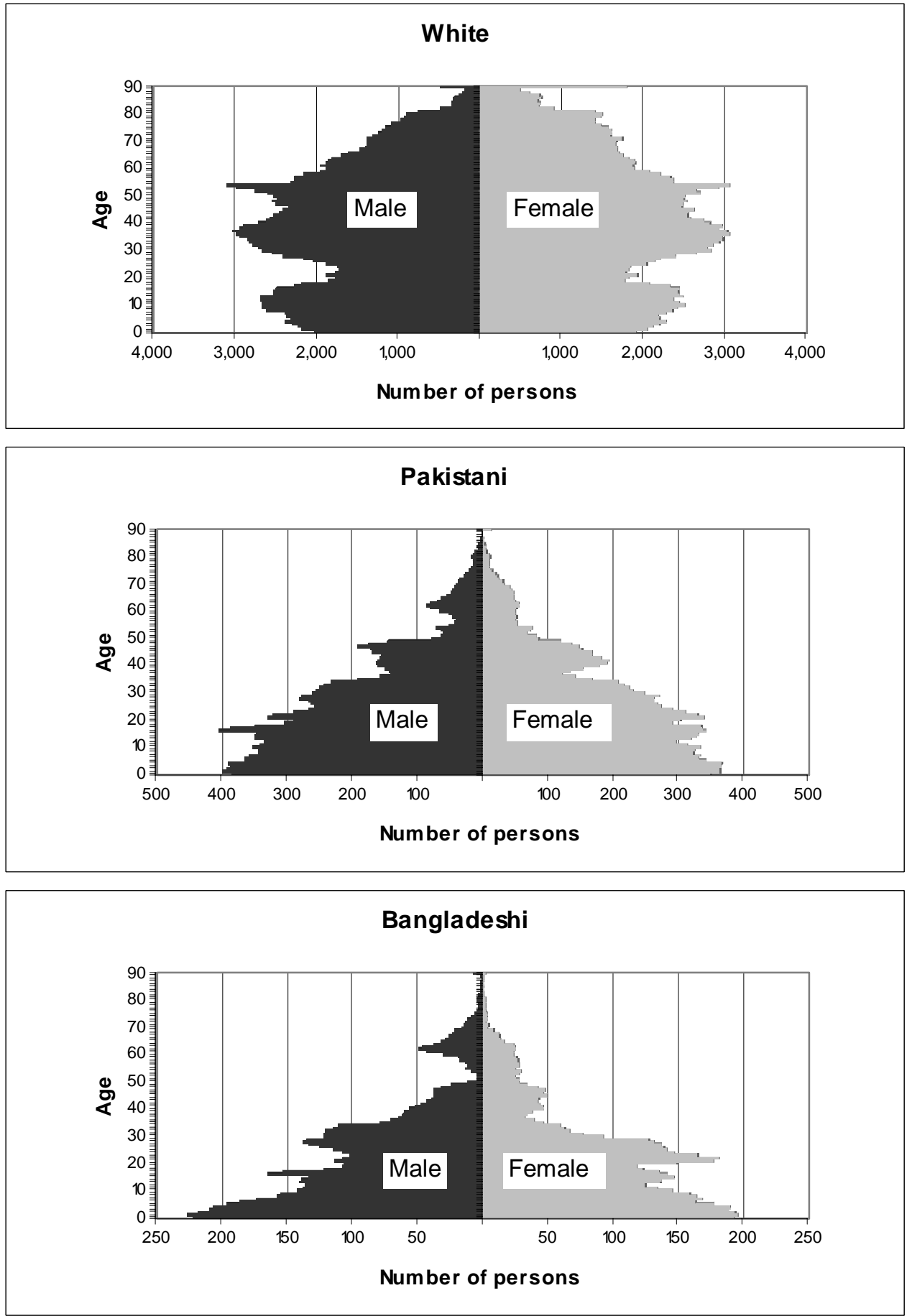

Source: 5-year age-sex groups from Census 2001, adjusted by the authors to single year of age and with full allowance for non-response. 
Figure 2 Classification of Housing Market Renewal neighbourhoods

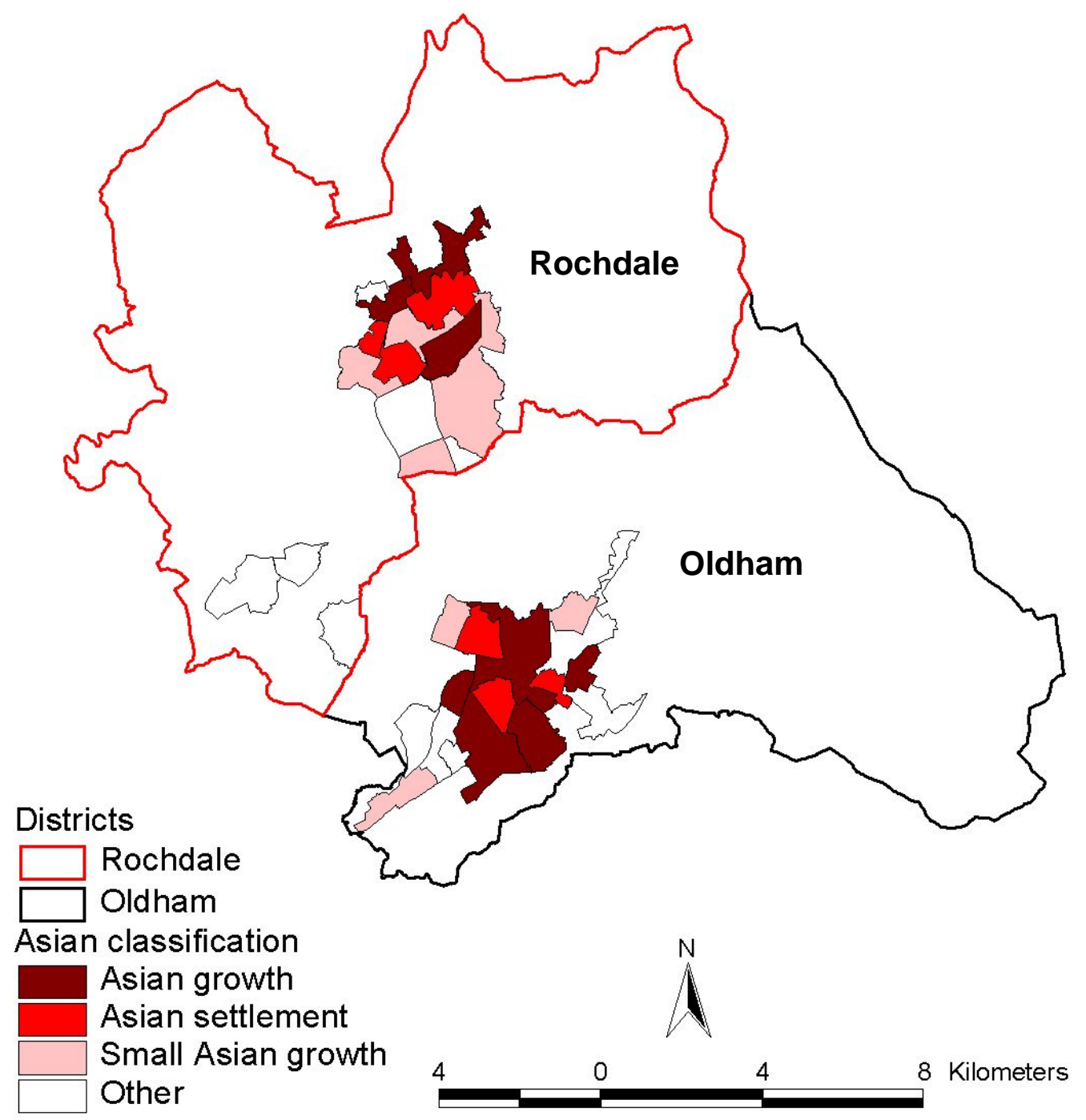


Figure 3 Average household size and number of adults per household

\begin{tabular}{|c|c|c|}
\hline \multicolumn{3}{|c|}{ White households } \\
\hline 6.0 & & 6.0 \\
\hline 5.0 & & 5.0 \\
\hline 4.0 & & 4.0 \\
\hline 3.0 & $\begin{array}{l}\text { Average household size } \\
\text { including children }\end{array}$ & 3.0 \\
\hline 1.0 & $\begin{array}{l}\text { Average adults per } \\
\text { household }\end{array}$ & 1.0 \\
\hline \multicolumn{2}{|c|}{0.0} & 0.0 \\
\hline \multicolumn{2}{|c|}{1991} & \\
\hline
\end{tabular}

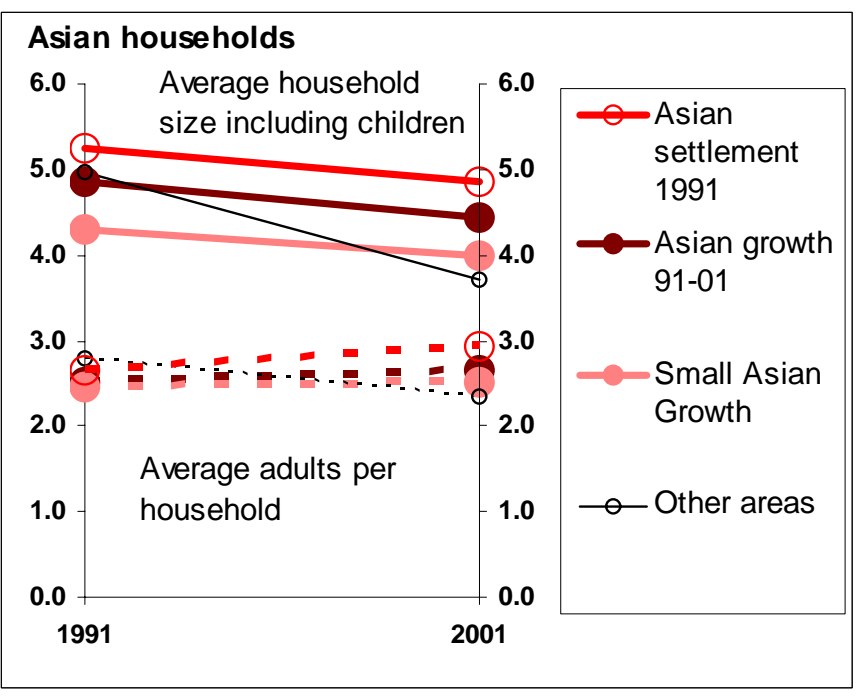

